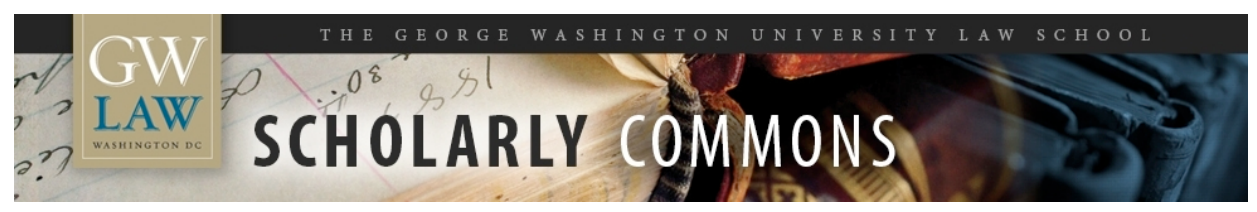

\title{
The (Neglected) Employment Dimension of the World Trade Organization
}

Steve Charnovitz

George Washington University Law School, scharnovitz@law.gwu.edu

Follow this and additional works at: https://scholarship.law.gwu.edu/faculty_publications

Part of the Law Commons

\section{Recommended Citation}

Steve Charnovitz, The (Neglected) Employment Dimension of the World Trade Organization in SOCIAL ISSUES, GLOBALIZATION AND INTERNATIONAL INSTITUTIONS: LABOUR RIGHTS AND THE EU, ILO, OECD and WTO, (Virginia Leary \& Daniel Warner, eds., Martinus Nijhoff Publishers, 2006).

This Article is brought to you for free and open access by the Faculty Scholarship at Scholarly Commons. It has been accepted for inclusion in GW Law Faculty Publications \& Other Works by an authorized administrator of Scholarly Commons. For more information, please contact spagel@law.gwu.edu. 


\title{
The (Neglected) Employment Dimension of the World Trade Organization
}

\author{
Steve Charnovitz*
}

A key assumption underlying the World Trade Organization (WTO) is that its program of trade negotiations will "strengthen the world economy and lead to more trade, investment, employment and income growth throughout the world." Indeed, that was the first point included in the Marrakesh Declaration of April 1994 that consummated the Uruguay Round and established the WTO. In my view, the WTO truly is strengthening the "world economy"2 and promoting trade and investment in many parts of the world. ${ }^{3}$ Yet the rest of the thesis is debatable. Is it necessarily true that the WTO and the trade negotiations it sponsors are increasing employment and income growth throughout the world? Indeed, even aggregating the world economy into one planetary unit, one wonders whether increased trade (and its ensuing dynamic efficiencies) inevitably increases the

* Forthcoming, Social Issues, Globalization and International Institutions: Labour Rights and the $E U, I L O, O E C D$ and WTO (Virginia Leary \& Daniel Warner (eds.), Martinus Nijhoff Publishers, 2006), available at <http://www.brill.nl/product_id23991.htm).

${ }^{1}$ Marrakesh Declaration of 15 April 1994, para. 1, available at <http://www.worldtradelaw.net/uragreements/index.htm>.

${ }^{2}$ The meaning of "world economy" is ambiguous. It could be the aggregate of all national economies or the portion of that aggregate involved in or affected by transborder transactions. On the latter definition, there could be some individuals who live outside the world economy. To "strengthen" an economy is to assist it to utilize full capacity and to grow.

${ }^{3}$ See Anne O. Krueger, Wilful Ignorance: The Struggle to Convince the Free Trade Skeptics, 3 World Trade Review 483 (2004). 
quantity of global employment. Even if it does, what is the quality of the jobs created? Does the WTO promote what the International Labour Organization (ILO) calls "decent work"4 ?

Such questions underlie the subject of this article - the neglected employment dimension of the WTO. As a non-economist, I do not propose to answer these questions empirically. Instead, the purpose of this article is to point out how little the WTO does to monitor these issues or to design trade rules with sensitivity to the objective of employment growth. So far, the WTO has not set any quantitative goals for income or employment growth. The trade ministers have alluded to their desire that the WTO promote the "benefit and welfare of their peoples," but the ministers are lackadaisical about keeping WTO negotiations on schedule. In view of the broad nature of international trade law today, the WTO seems to be overlooking many opportunities to promote a positive employment agenda.

This article proceeds in four parts: Part I reviews the WTO's actions, and inactions, on the issue of employment. Part I also provides an overview of the employment-related provisions of WTO law. Part II provides an historical context for thinking about the status of employment issues in the WTO. Part III presents an agenda for incorporating an employment and social dimension into the work of the WTO. Part IV concludes.

\section{The WTO and Employment Policy}

In its first decade, the WTO did not show much sensitivity toward the plight of the workers of the world who produce goods and perform services being traded. Aside from occasional strikes by

\footnotetext{
${ }^{4}$ For a brief discussion of whether "decent work" is the right objective for the ILO's efforts, see Philip Alston, "Core Labour Standards" and the Transformation of the International Labour Rights Regime, 15 EJIL 457, 488-89 (2004. Alston's article raises important questions about the ILO's focus on core labor standards, a topic he returns to in this volume. For an engaging response, see Brian Langille, Core Labour Rights - the True Story (Reply to Alston), this volume.

${ }^{5}$ Marrakesh Declaration, supra note 1, para. 2.
} 
WTO Secretariat bureaucrats who claim to be underpaid, ${ }^{6}$ the WTO lacks an employment dimension. Despite many suggestions that it do so, the WTO did not extend observer status to the ILO pursuant to Article V of the WTO Agreement. ${ }^{7}$ Furthermore, the WTO did not sign a "Cooperation Agreement" with the ILO even though the WTO did sign them with the World Bank and the International Monetary Fund. ${ }^{8}$ Although it has set up a Committee on Trade and Development and a Committee on Trade and Environment, the WTO has not seen fit to establish a Committee on Trade and Employment. ${ }^{9}$ Indeed, the topic of employment and labor standards is so much a taboo in the halls of the WTO that after delegates heard that the Director-General of the ILO had been invited to speak at the WTO's 1996 Ministerial Conference in Singapore, there was so much grumbling that the chair of the WTO General Council was forced to rescind the invitation. ${ }^{10}$ That retreat was lamentable and also symbolic of the distaste of the trading system for matters relating to workers and employment.

${ }^{6}$ See WTO Work to Rule Threat, Financial Times, 23 October 1997, at 8; Frances Williams, WTO Staff to Step Up Action Over Pay, Financial Times, 10 December 2002, at 16; Frances Williams, WTO Staff to Disrupt World Bank Meeting, Financial Times, 13 May 2003, at 10.

${ }^{7}$ See Marrakesh Agreement Establishing the World Trade Organization (WTO Agreement), art. V:1.

${ }^{8}$ See WTO News, WTO and World Bank Sign Cooperation Agreement, 28 April 1997; Coherence in Global Economic Policymaking and Cooperation between the WTO, the IMF and the World Bank, WT/TF/COH/S/9, Note by the Secretariat, 11 October 2004.

${ }^{9}$ Some analysts have commended the WTO Committee on Trade and Environment as a successful experiment. See e.g., Gregory Shaffer, "If Only We Were Elephants": The Political Economy of the WTO's Treatment of Trade and Environment Matters, in Daniel L.M. Kennedy \& James D. Southwick (eds.), The Political Economy of International Trade Law. Essays in Honor of Robert E. Hudec (Cambridge, Cambridge University Press, 2002) at 349, 381.

${ }^{10}$ Labours of Love, Financial Times, 6 December 1996, at 13; Drusilla K. Brown, International Labor Standards in the World Trade Organization and the International Labor Organization, The Federal Reserve Bank of St. Louis Review, July/August 2000, at 105. 
The Preamble to the WTO Agreement affirms that trade and economic relations should be conducted with a view to achieving listed goals, including "ensuring full employment ..." "11 and yet little attention to employment was institutionalized into the operative provisions of the treaty. Article III of the WTO Agreement states: "With a view to achieving greater coherence in global economic policy-making, the WTO shall cooperate, as appropriate, with the International Monetary Fund and with the International Bank for Reconstruction and Development and its affiliated agencies." ${ }^{\text {12 }}$ Unfortunately, that provision takes a narrow view of "coherence" in global economic policymaking, and does not give consideration to employment policymaking. Of course, the WTO Agreement does affirm that the WTO General Council "shall make appropriate arrangements for effective cooperation with other intergovernmental organizations that have responsibilities related to those of the WTO."13 That mandate is sufficient to justify cooperative arrangements with the ILO. But so far the General Council has not sought or agreed to such an arrangement.

The neglect of employment issues within the WTO seems likely to persist. The WTO website explains that "there is no work" on the subject of labor standards being carried out at the WTO and it would be "wrong" to assume that this subject lies ahead. ${ }^{14}$ This statement refers to labor standards, however, and not to the broader issue of employment. Yet with very limited exceptions, the same

\footnotetext{
${ }^{11}$ See WTO Agreement, Preamble, para. 2. The language about full employment was lifted directly from the General Agreement on Tariffs and Trade (GATT) written in 1947. In its decision in the Tariff Preferences case, the Appellate Body stated that the Preamble "informs" all WTO covered agreements. European Communities - Conditions for the Granting of Tariff Preferences to Developing Countries, Report of the Appellate Body, WT/DS246/AB/R, para. 161 (adopted 20 April 2004).

${ }^{12}$ WTO Agreement, art. III:5.

${ }^{13}$ WTO Agreement, art. V:1. Similar authority is found in GATT arts. XXXVI:7, XXXVIII:2(b)(c); General Agreement on Trade in Services (GATS), art. XXVI.

${ }^{14}$ WTO, Labour Standards: Highly Controversial, available at $<$ http://www.wto.org/english/thewto_e/whatis_e/tif_e/bey5_e.htm>.
} 
dismissive attitude seems to exist for employment. The most recent World Trade Report published by the WTO gives only scant attention to the labor market and job creation. ${ }^{15}$

Although less than five pages of the 200-page World Trade Report 2004 discuss labor issues, the substance of this analysis should be noted because it illustrates the WTO's unsympathetic attitude. The overall point made is that the "social acceptance of trade reforms" can be a political constraint to such reform because of "pressure" from employees in import-competing sectors. ${ }^{16}$ The Report explains that while other reforms, such as "a reduction of legal minimum wages" will exert effects "across the economy," trade liberalization is different because the adjustment costs tend to be concentrated in particular sectors of the economy. ${ }^{17}$ This pattern of concentration, it is said, can lead to "well organized resistance against trade reform." ${ }^{18}$ In the Secretariat's view, the "functioning of labor markets" has impact both on the size and length of the adjustment burden. ${ }^{19}$ For example, the Secretariat warns that "employment protection policies" may "discourage entrepreneurs from hiring the few workers needed for starting up a new company . ..." ${ }^{20}$ Furthermore, it warns that " $[\mathrm{h}] \mathrm{igh}$ minimum wages may lead to excessive lay-offs .... ${ }^{, 21}$ Another factor the Secretariat analyzes is the level of unionization in import-competing sectors. The Secretariat explains that higher unionization may increase resistance to liberalization and lead to "half-hearted adoption of reforms" or, even

\footnotetext{
${ }^{15}$ See WTO, Exploring the Linkage Between the Domestic Policy Environment and International Trade, World Trade Report 2004. The issue of employment was absent from the World Trade Report 2003.

${ }^{16}$ World Trade Report 2004, supra note 15, at 181.

${ }^{17}$ Id. at 182 .

${ }^{18} \mathrm{Id}$.

${ }^{19}$ Id. at 183 .

${ }^{20} \mathrm{Id}$.

${ }^{21} \mathrm{Id}$.
} 
worse, "[trade] policy reversals, with negative consequences for adjustment." ${ }^{22}$ Furthermore, according to the Secretariat, "trade is expected to decrease the demand for unskilled labour in industrial countries, and to decrease their wages relative to the wages of skilled workers." ${ }^{23}$

On a more positive note, the Report briefly discusses the need for "more sophisticated safety nets" to reduce the adjustment burdens carried by the poorest workers. ${ }^{24}$ No details are given as to how to accomplish this.

Three problems are apparent in the Secretariat's treatment of employment issues. First, by discussing the labor market merely as a constraint on trade liberalization, the Report seems to regard international trade as an end in itself rather than a means for humans to improve their happiness. The central challenge of economic development is how to weave together human resources, capital investment, technology, management, and good governance. Yet the Secretariat shows little appreciation for the larger context. Second, the implication in the Report that countries would be better off with less protection for employment, lower minimum wages, and less unionization shows a callous disregard for social values espoused by the international community. Third, in one area where the Secretariat could have collected information on better practices for carrying out worker adjustment programs, the Secretariat did not offer any useful advice.

In April 2003, the Secretariat published a Special Study on Adjustment by Marc Bacchetta and Marion Jansen, two staffers in the WTO Secretariat. ${ }^{25}$ Commissioning this Study was commendable, and was the first time that such an effort has been undertaken in the multilateral

\footnotetext{
${ }^{22} \mathrm{Id}$.

${ }^{23}$ Id. at 185 .

${ }^{24}$ Id. at $185-86$.

${ }^{25}$ Marc Bacchetta \& Marion Jansen, Adjusting to Trade Liberalization, WTO Special Studies 7, April 2003, available at <http://www.wto.org/english/res_e/reser_e/special_studies_e.htm>.
} 
trading system. The two authors make no claim that trade liberalization increases employment. ${ }^{26}$ Instead, they focus on the pockets of industry and job displacement and point out that the adjustment costs from trade liberalization are likely to be small relative to the gains from trade. The Study provides a thoughtful handbook of the various policies available to governments to address these adjustment costs. Oddly, most of the attention in the 60-page study is directed to trade policies for delaying adjustment, such as WTO transition and phase-in periods, regular safeguards, special agricultural and textile safeguards, and antidumping duties. By contrast, the option of facilitating positive worker adjustment is squeezed into three pages.

One of the most perceptive observations in the study is that aid for dislocated workers can include both (1) short-run assistance to facilitate adjustment and achieve efficiency and (2) long-run equity transfers to compensate workers for income losses. The Study goes on to explain that tensions exist between these distinct objectives. ${ }^{27}$ As someone who worked in the United States on the worker assistance problem for many years, I believe that this particular insight has often not been appreciated by analysts who criticize shortcomings in achieving one of these objectives without paying due attention to the other.

This mild praise for the Study's contributions on worker adjustment should be leavened by a brief recital of the Study's weaknesses. First, it is more of a literature review than a real study, and the literature reviewed is drawn mainly from trade economists. Second, the Study is not detailed enough to provide help to a WTO Member government attempting to design programs to assist workers who lose their jobs as a result of trade. Third, although the authors note that the costs of

\footnotetext{
${ }^{26}$ Id. at 18.

${ }^{27}$ Id. at 23, 31 Another thoughtful observation is that making trade commitments in the WTO enhances the credibility of reform efforts and signals to the factors of production that adjustment will be necessary. Id. at 39-40.
} 
adjustment will often be four percent or less of the gains from trade, ${ }^{28}$ the Study makes no effort to consider how to channel more of these net gains into aiding dislocated workers.

So far, this article has pointed out how little the WTO has done on the topic of employment. To be sure, the WTO was set up to be a trade agency, not a labor agency. Nevertheless, one should recognize that the issue of employment is already embedded to a limited extent in WTO rules, and so the WTO does have some jurisdictional competence on employment.

\section{Employment Aspects of Current WTO Rules}

The WTO Agreement and its annexes do not contain a labor chapter in the way that recent and emerging United States (U.S.) free trade agreements do. ${ }^{29}$ Indeed the term "worker" is not even mentioned in the WTO Agreement, as if the goods in international trade were immaculately produced. Although there is limited attention to labor, employment, and social matters in the covered WTO Agreements, no common thread of labor policy can be said to exist. The best way for explicating the labor-related elements of WTO law is to point out the specific rules in various agreements.

The General Agreement on Tariffs and Trade (GATT) has several provisions relating to employment, but all have been neglected. GATT Article XII states a commitment of governments to pay due regard to the "desirability of avoiding an uneconomic employment of productive resources. ${ }^{{ }^{30}}$ Referring to safeguards related to the balance of payments, Article XII also provides a modicum of deference to domestic policies directed toward the achievement and maintenance of "full

\footnotetext{
${ }^{28}$ Id. at $16-17$.

${ }^{29}$ See Thomas J. Manley \& Luis Lauredo, International Labor Standards in Free Trade Agreements in the Americas, 18 Emory International Law Review 85 (2004).
}

${ }^{30}$ GATT art. XII:3(a). See also GATT art. XVIII:11 first sentence. 
and productive employment." ${ }^{31}$ In GATT Part IV, the objective of "social" advancement is noted alongside "economic" advancement. ${ }^{32}$ Nothing significant has resulted from any of these provisions.

Employment also plays a role in other WTO agreements covering trade in goods. For the purpose of invoking trade remedies, the impact of imports on wages and/or employment is a factor in determining the existence of injury. ${ }^{33}$ An import-restricting safeguard is to be imposed "only to the extent necessary to prevent or remedy serious injury and to facilitate adjustment. ${ }^{{ }^{34}}$ In practice, however, since the term "adjustment" is not defined, the WTO has not required governments using safeguards to assure that employers (or their workers) are seeking to adjust to a global economy. ${ }^{35}$

The WTO rules regarding subsidies also contain some employment policy. Some of these rules support employment policy. For example, in defining when a domestic subsidy causes "serious prejudice" to a competing WTO member country, the Agreement on Subsidies and Countervailing Measures (SCM Agreement) exempts one-time subsidies "to avoid acute social problems." ${ }^{\text {"36 }}$ For developing countries, time-delimited privatization subsidies to cover "social costs" are exempt from the disciplines on actionable subsidies. ${ }^{37}$ For all countries, certain subsidies for agricultural training services are exempt from reduction commitments. ${ }^{38}$ On the other hand, other substantive rules do not

\footnotetext{
${ }^{31}$ GATT art. XII:3(d).
}

${ }^{32}$ GATT art. XXXVI:1(e).

${ }^{33}$ Agreement on Subsidies and Countervailing Measures (SCM Agreement), art. 15.4; Agreement on Safeguards, art. 4.2(a); Agreement on Implementation of Article VI of the GATT (Antidumping Agreement), art. 3.4. A similar reference appears in the now-terminated Agreement on Textiles and Clothing, art. 6.3.

${ }^{34}$ Agreement on Safeguards, art. 5.1. See also arts. 7.2, 7.4.

${ }^{35}$ See Bacchetta \& Jansen, supra note 25, at 50-52 (discussing the Safeguards Agreement).

${ }^{36} \mathrm{SCM}$ Agreement, art. 6.1(c). A subsidy causing serious prejudice will be actionable.

${ }^{37}$ Id. art. 27.13.

${ }^{38}$ Agreement on Agriculture, Annex 2, para. 2(c). 
support employment policy. For example, the rules against export subsidies prohibit the remission of "social welfare" charges upon exportation. ${ }^{39}$ For domestic subsidies, a complaining government cannot claim that a subsidy in one country is displacing or impeding its exports to a third country when the complaining country has suffered strikes affecting its exports. ${ }^{40}$ Initially, the SCM Agreement removed its disciplines on subsidies for a disadvantaged region suffering a spike in unemployment. ${ }^{41}$ But that forbearance expired in 2000 , and so high unemployment is no longer a justification for a subsidy. ${ }^{42}$

Note that all government subsidies for workers or for social costs will be subject to the control of the Byrd Amendment decision. In that controversial holding, the WTO Appellate Body ruled that companies suffering injury from dumping or foreign subsidies cannot receive government aid when the source of the funding are revenues collected via antidumping or countervailing duties. ${ }^{43}$ This is the first WTO decision to dictate how a government budgets sources of revenue for carrying out social policy.

In the General Agreement on Trade in Services (GATS), there are several significant provisions that cover employment. The GATS provides deference for certain "Labor Markets Integration Agreements." ${ }^{\prime 4}$ The GATS directs governments to devise adequate procedures to verify

\footnotetext{
${ }^{39}$ SCM Agreement, Annex I, para. e. This means that a government may not give exporters a rebate on payroll taxes paid even though rebates may be given on value-added taxes paid.

${ }^{40}$ Id. art. 6.7(c). Other grounds for demonstrating serious prejudice would continue to exist.

${ }^{41}$ Id. art. 8.2(b).

${ }^{42}$ See id. art. 31.

${ }^{43}$ United States - Continued Dumping and Subsidy Offset Act of 2000, Report of the Appellate Body, WT/DS217,234/AB/R (adopted 27 January 2003).

${ }^{44}$ GATS art. V bis. On the role of bilateral and regional labor agreements, see Virginia Leary, Labor Migration, in T. Alexander Aleinikoff \& Vincent Chetail (eds.), Migration and International Legal Norms (The Hague, Asser Press, 2003), at 227, 229.
} 
the competence of foreign professionals. ${ }^{45}$ The GATS directs governments, wherever appropriate, to work in cooperation with relevant intergovernmental organizations and non-governmental organizations toward "the establishment and adoption of common international standards" for the practice of service trades and professions. ${ }^{46}$ The GATS forbids limitations on the total number of natural persons "that may be employed in a particular service sector or that a service supplier may employ ..." when such limitations are in the form of numerical quotas or the requirement of an economic needs test. ${ }^{47}$

Furthermore, the labor market is central to GATS because two of the four modes for trade in services can involve the movement of people. ${ }^{48}$ Mode 2 is the movement of individuals (and companies) to consume services in another country (e.g., training). Mode 4 is the movement of "natural persons" (i.e., individuals) to deliver services in another country (e.g., anti-terrorism services).

The precise boundary of Mode 4 is yet to be delineated or adjudicated. According to the GATS Annex on Movement of Natural Persons Supplying Services Under the Agreement, the movement of employees is covered, but the GATS does not apply to measures affecting persons "seeking access to the employment market" and does not apply to measures regarding "employment on a permanent basis." ${ }^{49}$ These provisions are puzzling because a worker who relocates to another country as an employee of a company may not be searching for a job, and yet is still statistically part

\footnotetext{
${ }^{45}$ GATS art. VI:6 (in sectors where specific commitments are undertaken).

${ }^{46}$ Id. art. VII:5.

${ }^{47}$ Id. art. XVI:2(d). This discipline applies only to sectors where market access commitments are undertaken and may be avoided by inscribing the quota within the national schedule.
}

${ }^{48}$ See GATS art. I:2; B.S. Chimni, Development and Migration, in Migration and International Legal Norms, supra note 44, at 256, 266.

${ }^{49}$ GATS Annex on Movement of Natural Person Supplying Services Under the Agreement, paras. 1, 2. 
of the employment market of the receiving country. ${ }^{50}$ Another unknown is whether the "employment market" includes the self-employed who may offer various labor services.

Mode 4 of the GATS applies to national law governing entrance into a country (i.e., often termed "immigration"), the issuance of visas, and the administration of visa quotas. This is implicitly shown by the Annex's specific exclusion of measures regarding citizenship and residence, ${ }^{51}$ and by the statement in the Annex that GATS "shall not prevent a Member from applying measures to regulate the entry of natural persons into, or their temporary stay in, its territory, including those measures necessary to protect the integrity of, and to ensure the orderly movement of natural persons across, its borders, provided that such measures are not applied in such a manner as to nullify or impair the benefits accruing to any Member under the terms of a specific commitment. ${ }^{, 52}$ In other words, if immigration measures necessary to protect border integrity are applied so as to impair specific commitments, then such measures can violate the GATS. The applicability of the GATS to visas is further clarified by the footnote to Paragraph 4 of the Annex which states that: "The sole fact of requiring a visa for natural persons of certain Members and not for those of others shall not be regarded as nullifying or impairing benefits under a specific commitment. ${ }^{953}$ What this means is that the mere existence of a country-specific visa formality (perhaps due to reciprocity) is not in itself to be considered a nullification of benefits.

\footnotetext{
${ }^{50}$ In other words, she has access already even though she is not seeking access. For example, consider a transnational corporation that provides childcare services to residents in the United States through the use of foreign service suppliers who are already employed by the corporation and therefore arguably not seeking access to the U.S. labor market. The reality is that such a person operates in the U.S. labor market.

${ }^{51}$ Annex on Movement of Natural Person Supplying Services Under the Agreement, para. 2.

${ }^{52}$ Id. para. 4 (footnote omitted).

${ }^{53}$ Id. at n. 13.
} 
Notwithstanding constitutional authority to do so, ${ }^{54}$ the GATS Council, to my knowledge, has not consulted with the most relevant international organizations on employment and migration regarding the interpretation and implementation of the Mode 4 provisions. Those organizations are the ILO and the International Organization for Migration (IOM). However the provisions are interpreted, it seems likely that the GATS will lead to a greater movement of workers across borders and some of those workers will decide to stay permanently.

\section{Summary}

In summary, during its first decade, the WTO missed numerous opportunities to solidify a constructive employment dimension. The WTO did not engage in significant cooperation with the ILO, did not establish a Committee on Trade and Employment, did not tackle the problem of helping workers adversely affected by trade, and did not reauthorize the exemption for subsidies to highunemployment areas. Even though the current WTO trade negotiations, known as the Doha Round, is ostensibly about development and poverty alleviation, the WTO has not yet agreed that employment is crucial to poverty alleviation. United Nations (U.N.) Secretary-General Kofi Annan put that matter succinctly in September 2004 when he declared: “After all, the best anti-poverty programme is employment." ${ }^{55}$ Unfortunately, that simple insight has not noticeably influenced thinking at the WTO.

Given that several provisions in WTO law do pertain to employment, the WTO could have acknowledged that a labor dimension to WTO law already exists, and thus moved beyond the denial of a linkage that so often permeates WTO discourse regarding labor. Although past mistakes cannot be undone, the WTO can outgrow its insularity. Before discussing in Part III what the WTO should do, Part II will provide some historical context for thinking about social issues in trade policy.

\footnotetext{
${ }^{54}$ GATS art. XXVI.

${ }^{55}$ Secretary-General Affirms Commitment to Achieving Fair, Inclusive Globalization, Press Release SG/SM/9487/DEV/2487 (20 September 2004).
} 


\section{The Awakening of Social Awareness in Trade Policy}

As always, the beginning of wisdom in thinking about the future is looking to the past. Both Adam Smith and Karl Marx shared an understanding that international trade has significant social implications, with Smith criticizing the pathologies of protection and Marx praising the revolutionary potential of free trade. ${ }^{56}$ In the interwar period, the first ILO Director, Albert Thomas, offered a visionary synthesis of an emerging "world economy" and "new economic organisation" in which labor protections and free trade are complementary. ${ }^{57}$

On a multilateral basis, action to regulate trade for social reasons began in the early 20th century with conventions to restrict trade in sexual services of women (1904) and trade in toxic phosphorus matches (1906).$^{58}$ The earliest ILO recommendation on trade came in 1919 with the Recommendation Concerning the Prevention of Anthrax (No. 3).

The efforts of the League of Nations against economic instability helped to enlighten pragmatic policymakers regarding the interplay between trade and employment. In 1927, the World Economic Conference made several recommendations on trade policy and also gave some attention to rationalization in industry as a means of improving the conditions of labor ${ }^{59}$ In 1939 , the Bruce Committee observed the phenomenon of physical, economic, and moral contagion among countries, and emphasized the need for international cooperation and coordination through "mutual help," "exchange of knowledge," and "association in the work of independent experts," in contrast to the

\footnotetext{
${ }^{56}$ See Adam Smith, An Inquiry into the Nature and Causes of the Wealth of Nations (1776), Book IV, chaps. ii, iii, v; Karl Marx, The Free Trade Congress at Brussels, 1847, available at < http://www.marxists.org/archive/marx/works/1847/09/30.htm>.

${ }^{57}$ See Albert Thomas, International Social Policy (Geneva, ILO, 1948), at 108, 114.

${ }^{58}$ International Agreement for the Suppression of the White Slave Traffic, 18 May 1904, 1 LNTS 83; Convention respecting the Prohibition of the Use of White (Yellow) Phosphorus in the Manufacture of Matches, 26 September 1906, 99 BFSP 986.

${ }^{59}$ See Wallace McClure, National Economic Independence in the Light of the International Economic Conference, 21 American Journal of International Law 668 (1927).
} 
technique of "settlement by formal conferences and treaties. ${ }^{" 60}$ Anticipating discoveries by social scientists several decades in the future, the Bruce Committee suggested that the League of Nations could contribute by establishing a "platform" for public knowledge and discussion in which direction would be given "by persons of Government rank directly concerned at home with the subjects of international discussion. ${ }^{{ }^{61}}$ Such transgovernmental cooperation was intended to integrate both economic and social considerations. ${ }^{62}$ In 1944, in its Declaration of Philadelphia, the ILO noted the objective of a broader utilization of the world's productive resources, including measures to promote a high and steady volume of international trade, and pledged ILO cooperation with such new international bodies as may be entrusted with these responsibilities. ${ }^{63}$ In 1945, when the U.N. Charter was drafted and approved, one of its provisions called for the United Nations to promote "higher standards of living, full employment, and conditions of economic and social progress and development." ${ }^{94}$

These and other milestones over several decades set the stage for the decision by the U.N. Economic and Social Council in 1946 to convene a Conference on Trade and Employment. The governments saw trade and employment as twin issues linked in both economics and law. ${ }^{65}$ Some negotiators emphasized that high levels of employment could enable trade liberalization and others

\footnotetext{
${ }^{60}$ The Development of International Co-operation in Economic and Social Affairs, Report of the Special Committee (Bruce Committee), Special Supplement to the Monthly Summary of the League of Nations, August 1939, at 7-9, 11. The Chairman of the Committee, S.M. Bruce, was a former Australian prime minister.

${ }^{61}$ Id. at 17. Compare Anne-Marie Slaughter, A New World Order (Princeton, Princeton University Press, 2004) (discussing transgovernmental networks).

${ }^{62}$ Bruce Committee Report, supra note 60, at 19.

${ }^{63}$ ILO Declaration concerning the Aims and Purposes of the International Labour Organisation (Declaration of Philadelphia), 10 May 1944 (annexed to the ILO Constitution).

${ }^{64}$ Charter of the United Nations, 26 June 1945, art. 55.

${ }^{65}$ See Susan Ariel Aaronson, Taking Trade to the Streets. The Lost History of Public Efforts to Shape Globalization (Ann Arbor, University of Michigan Press, 2001) at 52-53.
} 
emphasized that liberalization could strengthen the economy so that more employment could be achieved. ${ }^{66}$ Australia was the leading exponent of international undertakings on employment. ${ }^{67}$

The ensuing Havana Charter for an International Trade Organization (ITO) put employment first with a chapter on "Employment and Economic Activity." The core commitment was for each member government to "take action designed to achieve and maintain full and productive employment and large and steadily growing demand within its own territory through measures appropriate to its political, economic and social institutions. ${ }^{968}$ Furthermore, the ITO was authorized to initiate consultations among governments for appropriate measures against the international spread of a decline in employment, production or demand ${ }^{69}$ The Employment chapter also included Article 7 on "Fair Labour Standards" that provided for dispute settlement regarding unfairly low standards in another country. ${ }^{70}$ Recognizing the interconnections between the ITO and the ILO, the two organizations drafted a cooperation agreement in $1948 .^{71}$

The broad intended scope of the ITO is apparent not only in the ITO's chapter on "Employment and Economic Activity", but also in its chapters on "Economic Development and Reconstruction" and "Restrictive Business Practices." Several of the provisions regarding Economic Development and Reconstruction contain references to employment. For example, Article 10 directs

\footnotetext{
${ }^{66}$ See Richard N. Gardner, Sterling-Dollar Diplomacy (London: Oxford University Press, 1956) at 105.

${ }^{67}$ William Adams Brown, Jr., The United States and the Restoration of World Trade (Washington, Brookings, 1950) at 95.

${ }^{68}$ ITO Charter, art. 3. The text of the ITO Charter is available at $<$ http://www.wto.org/english/docs_e/legal_e/prewto_legal_e.htm>.

${ }^{69}$ Id. art. 5.2.

${ }^{70}$ Id. art. 7.

${ }^{71}$ Proposed Agreement between the International Labour Organisation and the International Trade Organisation, in ILO, Minutes of the 107th Session of the Governing Body, December 1948, at 169. The Agreement did not go into force due to the demise of the ITO.
} 
the ITO to cooperate with other international organizations to provide finance, equipment, technical assistance, and managerial skills to countries that were still relatively undeveloped. ${ }^{72}$ Article 11 authorizes the ITO to make recommendations for bilateral or multilateral agreements designed "to assure just and equitable treatment for the enterprise, skills, capital, arts and technology brought from one Member country to another." 73

For better or worse, the ITO did not come to fruition. Happily, the same U.N. negotiations spawned the GATT which served as a caretaker for world trade order over the next four decades. Perhaps in an effort to distance itself from the broad aspirations for the ITO, the GATT stayed away from employment policy.

To my knowledge, the only employment-related policy engaged in by the GATT was a joint study with the ILO begun in 1960 to analyze the factors underlying market disruption from textile imports produced by low-wage workers. ${ }^{74}$ Without waiting for the study to be completed, the trade ministers rushed in 1961 to undertake GATT arrangements to limit trade in cotton textiles. Those harmful arrangements metastasized for many years and were not eliminated until 2005. After the GATT staff lost interest in cooperative research regarding the international division of labor, the ILO finalized the study and published it in 1963. The conclusion reached by the ILO was that the problem of the textile industries in high-wage countries "cannot be primarily attributed to the alleged unfairness of competition from low-wage underdeveloped countries." ${ }^{\text {75 }}$

\footnotetext{
${ }^{72}$ ITO Charter, supra note 68, art. 10.
}

${ }^{73}$ Id. art. 11.2(a)(i).

${ }^{74}$ See Kenneth W. Dam, The GATT. Law and International Economic Organization (Chicago, University of Chicago Press, 1970) at 298-300.

${ }^{75}$ Gardner Patterson, Discrimination in International Trade. The Policy Issues (Princeton, Princeton University Press, 1966) at 306-07 \& n. 63. 
Unfortunately, the low-wage developing countries seeking to export their cotton and other apparel have been stymied for over 40 years because the GATT/WTO system has not been ready to accept the comparative advantage of those countries. ${ }^{76}$ Indeed, even today, some industrial countries use high tariffs to thwart such trade. For example, the U.S. government imposes 15 percent tariffs on many cotton products and 25 percent tariffs on many wool products.

In 1996, the WTO ministers pointed to ILO's standards as a possible threat to the export aspirations of developing countries. ${ }^{77}$ This statement dripped in irony because the blame for the protectionism of the past 40 years cannot be attributed to labor standards or to the ILO. Instead of isolating itself from the ILO, WTO should recognize that the ILO can help it overcome national fears about import competition.

\section{A Positive Employment Agenda for the WTO}

The most important contribution the WTO can make to raising standards of living would be to tear down the protectionist walls between economies. Liberalizing trade is hardly sufficient for achieving human dignity and other social goals of the community. But trade liberalization is a constructive policy in an interdependent world economy because it typically increases purchasing power in each country. Although the GATT and WTO have done a lot to remove protection, a great deal more remains to be done-particularly in developing countries that have the greatest need for an

\footnotetext{
${ }^{76}$ The WTO Agreement on Textiles and Clothing does not assert that the exports of developing countries being limited are unfair. Therefore, the motivation for keeping import quotas from 1995 to 2005 presumably was that the WTO was not ready to accept the comparative advance of low-wage countries.

${ }^{77}$ The WTO Singapore Ministerial Declaration states that "We reject the use of labour standards for protectionist purposes, and agree that the comparative advantage of countries, particularly low-wage developing countries, must in no way be put into question." WTO Singapore Ministerial Declaration, 13 December 1996, para. 4, available at $<$ http://www.wto.org/english/thewto_e/minist_e/min96_e/wtodec_e.htm>. As I pointed out after the Singapore Conference, the WTO ministers did not need labor standards for protectionist purposes because they were using trade measures for that self-defeating function. Steve Charnovitz, Trade, Employment and Labour Standards: The OECD Study and Recent Developments in the Trade and Labor Standards Debate, 11 Temple International and Comparative Law Journal 131, 156-57 (1997).
} 
economic boost from trade. Quite perversely, the developing countries are often the most resistant to liberalization.

Protectionism is not an effective or ethical response to any market failure; instead, it is a manifestation of government failure as politically powerful rent-seeking interests are requited with border restrictions. ${ }^{78}$ Although trade ministers can agree to a rhetorical rejection of protectionism, ${ }^{79}$ many of them remain eager to partake at home. Eradicating protectionism is a difficult political challenge for governments, and so the WTO should welcome outside offers to help.

Although the WTO epistemic community tends to look at employment as an output generated by trade negotiations, this view is incomplete in two respects. First, it fails to consider that high levels of employment within countries may be a necessary input for successful trade negotiations. That insight animated the founders of the postwar trading system who wrote the Employment chapter of the ITO Charter. Second, the current WTO program fails to consider the ways in which WTO rules may interfere with using employment policy at the national level to counter market failures and to increase investment in human capital. The WTO also fails to consider ways in which its cooperation with other international organizations, such as the ILO, could help those organizations achieve their own functional objectives.

\section{Worker Adjustment Assistance}

A recognition that governmental assistance to workers can be a complementary policy to trade liberalization goes back to the first half of the 20th century, but has not yet emerged in an intergovernmental treaty. So far, only soft law exists. In 1976, at the World Employment Conference, the governments, workers, and employers agreed to a Declaration which, among many points, states that governments should provide worker adjustment assistance "in order to facilitate the

\footnotetext{
${ }^{78}$ Smith, supra note 56 , chap. ii. He takes note of the way that "partial interests" direct and intimidate the legislature, moving it away from the general good.

${ }^{79}$ See, e.g., Doha Ministerial Declaration, WT/MIN(01)/DEC/1, para. 1 (adopted 20 November 2001).
} 
establishment of new economic relations between developing and developed nations." ${ }^{\prime 80}$ The Declaration further states that the worker delegates felt that in the context of multilateral trade negotiations, the ILO could "contribute to the improvement of an international safeguard system covering employment and income guarantees, fair labour standards and adjustment assistance." ${ }^{\not 1}$ In 1985, the GATT Eminent Persons Group recommended that safeguard actions "be linked with adjustment assistance including help, where necessary, to ease the transfer of workers. ${ }^{982}$ In 2005 , the WTO Consultative Board to the Director-General explained that "adjustment assistance programmes reflect the political need to offset the social impact of trade liberalization which would otherwise not be politically sustainable. ${ }^{" 83}$ The Board lamented that the WTO "says practically nothing, even by way of exhortations, to WTO Members and to aid-giving institutions, on adjustment assistance." ${ }^{84}$ To achieve greater "horizontal coordination" on adjustment, the Board recommended that international development agencies, in close cooperation with the WTO and other agencies, undertake programs to fund adjustment assistance for developing countries. ${ }^{85}$ The need for adjustment programs may be greater in developing countries, than in industrial countries, because some developing countries (such as China) face huge transitional problems as the agricultural population exits from subsistence farming.

\footnotetext{
${ }^{80}$ ILO, Declaration of Principles and Programme of Action adopted by the Tripartite World Conference on Employment, Income Distribution and Social Progress, and the International Division of Labour, June 1976, para. 66. See also para. 69 ("Adjustment assistance is considered preferable to import restrictions.").

${ }^{81}$ Id. para. 76. Also in 1976, the need for such policies was briefly discussed in the Tinbergen report. Jan Tinbergen (coordinator), Reshaping the International Order. A Report to the Club of Rome (New York, E.P. Dutton \& Co., Inc., 1976) at 113-14, 145.

${ }^{82}$ Fritz Leutwiler et al., Trade Policies for a Better Future (Geneva, GATT, 1985) at 43.

${ }^{83}$ Peter Sutherland et al., The Future of the WTO (Geneva, WTO, 2005), para. 172.

${ }^{84}$ Id. para. 42.

${ }^{85}$ Id. para. 172.
} 
Over the years, trade adjustment programs have typically been ineffectual and are regularly criticized by economists and derided by labor unions. ${ }^{86}$ Such programs have remained ineffective because their presumptive constituency - workers, employers, and free traders - are often uninterested in a pro-adjustment approach. ${ }^{87}$ This is not true of all academic economists however. ${ }^{88}$ For example, in a recent book on the WTO, Kent Jones explained that "Governments have the responsibility to make sure that the policy environment facilitates adjustment to trade. . . The easier it is for a displaced worker to find a new job, the less will be her trepidation about trade and the WTO." $"$ Jones does not recommend any specific action by the WTO toward that end however. Beyond the academy, one thoughtful study was written a few years ago by Cletus C. Coughlin, a vice president of the Federal Reserve Bank of St. Louis, who pointed out the need to reduce the cost for those harmed by trade..$^{90}$

Worker adjustment programs are controversial in several respects: One issue is whether there should be specific programs targeted at workers hurt by trade, or instead more general programs to

\footnotetext{
${ }^{86}$ For example, see the arguments by Doug Irwin, an eminent trade economist, in Douglas A. Irwin, Free Trade Under Fire (Princeton, Princeton University Press, 2002) at 100-110. Amazingly, in my view, Irwin proposes to drop the requirement in U.S. law that displaced workers should be enrolled in appropriate training. Id. at 108.

${ }^{87}$ See Steve Charnovitz, Worker Adjustment: The Missing Ingredient in Trade Policy, 28 California Management Review 156, 167 (1986).

${ }^{88}$ The most well-known exception among trade economists is the Washington-based Institute for International Economics which has consistently published cutting-edge research on how to make better use of trade adjustment programs as a political economy strategy to improve the prospects for trade liberalization. The key analysts have been Robert E. Baldwin, Fred Bergsten, Gary Hufbauer, Catherine Mann, David Richardson, and Howard Rosen. See, e.g., C. Fred Bergsten, A New Foreign Economic Policy for the United States, in C. Fred Bergsten and the Institute for International Economics, The United States and the World Economy (Washington, Institute for International Economics, 2005) at 3,18-19 (discussing the role of trade adjustment assistance as an integral component of U.S. foreign economic policy).

${ }^{89}$ Kent Jones, Who's Afraid of the WTO? (Oxford, Oxford University Press, 2004) at 61.

${ }^{90}$ Cletus C. Coughlin, The Controversy Over Free Trade: The Gap Between Economists and the General Public, The Federal Reserve Bank of St. Louis Review, January/February 2002, at 1.
} 
help all workers who suffer from structural unemployment. Another issue is whether adjustment programs are worth the public monies being spent on them. Although a full discussion of these issues is beyond the scope of this article, let me briefly offer my own views. If governments undertook active labor market programs for all workers who needed them, then there would be no need for categorical programs for trade-affected workers. Conversely, when generally-available programs are absent or spotty (which is the condition in nearly all countries), the ideal of treating workers equally is not a good reason to refrain from some groups of workers. In other words, do not let the best be the enemy of the good.

The challenge of effectiveness is a much deeper problem because evaluations sometimes do not show a significant positive impact for retraining. Recognizing, however, how little resources and management attention have been devoted to such programs over the past 25 years, I am not surprised by the disappointing results. In my view, society can help the structurally unemployed if we try. The task is not just only for governments however; companies and workers themselves need to be engaged in the process. Thus, I agree with a statement in a recent Paper published by the World Bank that "Despite the mixed evaluation picture, governments have little choice but to use active programming as one instrument in their response to the economic and social problems associated with unemployment and poverty in the labor force." ${ }^{.1}$

Based on the U.S. experience, one mistake that has been made is to assume that adjustment programs can be effectively implemented by the public sector. Instead, I would opt for a model of privatization of active labor market programs whereby individuals who need services are empowered with government-issued vouchers which individuals combine with their own money to purchase

\footnotetext{
${ }^{91}$ Gordon Betcherman, Karina Olivas \& Amit Dar, Impacts of Active Labor Market Programs: New Evidence from Evaluations with Particular Attention to Developing and Transition Countries, World Bank Social Protection Discussion Paper Series, No. 0402, January 2004, at iii.
} 
needed services. The government could encourage individual saving for that purpose through the tax system.

\section{A WTO Decision on Trade and Employment}

As a focal point for its new efforts, the WTO should enact a Decision on Trade and Employment to better institutionalize the employment issue in WTO policy. Such a Decision could include one or more of the following specifics:

-Restate the principle from the ITO Charter ${ }^{92}$ that the avoidance of unemployment is not of domestic concern alone, but is also a condition for achieving the general purposes of the trading system.

-Exhort WTO Members to establish programs to assist dislocated workers and propose that appropriate international organizations - such as the ILO and the World Bankpromote informational hubs and technical assistance for counseling, retraining, mobility assistance, and wage insurance. Governments need help in knowing what the better practices are. The Decision might recall the endorsement of adjustment programs by the World Summit for Social Development. ${ }^{93}$

-Propose that the World Bank set up a fund for developing countries to assist them in providing adjustment aid to workers dislocated by globalization. The Decision might recall that the idea of such international funding originated at the World Employment Conference in $1976 .^{94}$

-Propose that an independent mechanism be set up to collect data on the efficacy of national adjustment programs and to evaluate those programs, and then to put those results on the WTO website.

-Propose that experimentation in social safety nets be encouraged through an international prize to be awarded to the most innovative and successful programs.

•Hold GATS negotiations to lower barriers to trade in worker adjustment services. ${ }^{95}$ If service deliverers see a large international market in delivering such services to

\footnotetext{
${ }^{92}$ See ITO Charter, supra note 68 , art. 2.1.

${ }^{93}$ World Summit for Social Development, Programme of Action of the World Summit for Social Development, para. 52(g), available at <http://www.un.org/esa/socdev/wssd/agreements/index.html >.

${ }^{94}$ Declaration, supra note 80, para. 71. Jagdish Bhagwati has endorsed this idea. Jagdish Bhagwati, In Defense of Globalization (Oxford, Oxford University Press, 2004) at 235.
}

\footnotetext{
${ }^{95}$ All four GATS modes are relevant here.
} 
workers, more providers will get involved and their performance will be strengthened through competition.

-Expand the WTO research program and direct the WTO to work with the ILO and the U.N. Conference on Trade and Development to examine the impact of trade on the quantity and quality of employment, and the gender implications of this impact. ${ }^{96}$ The Decision might recall that this recommendation for joint research was made by the World Commission on the Social Dimension of Globalization. ${ }^{97}$

-Establish a WTO Committee on Trade and Employment. ${ }^{98}$ The Committee should be asked to examine whether WTO rules unduly constrain adjustment programs and national employment promotion policies. The Decision should invite the ILO to participate in the new Committee through a tripartite delegation. The Committee should also formulate measurable objectives for the WTO regarding world employment growth.

- Consider the advisability of amending GATT rules to allow any country to impose a small uniform fee on imports for the purpose of using the revenue from such a fee to fund programs for adjustment assistance. ${ }^{99}$

In my view, the remit of a WTO Committee on Trade and Employment should be limited to these issues and should not include the two controversial topics discussed below-worker migration and fair labor standards. ${ }^{100}$

\footnotetext{
${ }^{96}$ See Eugenia McGill, Poverty and Social Analysis of Trade Agreements: A More Coherent Approach?, 27 Boston College International and Comparative Law Review 371 (2004).

${ }^{97}$ World Commission on the Social Dimension of Globalization, A Fair Globalization (Geneva, ILO, 2004), para. 628. James Salzman has argued that the Organization for Economic Co-operation and Development can also play a useful role in research on this topic. James Salzman, Labor Rights, Globalization and Institutions: The Role and Influence of the Organization for Economic Cooperation and Development, 21 Michigan Journal of International Law 769 (2000). Salzman takes issue with my criticisms of the OECD's first study on the trade-labor connection. Id. at 799 n. 75.
}

${ }^{98}$ I urged this in 1995. See Steve Charnovitz, Strengthening the International Employment Regime, 30 Intereconomics 221, 233 (1995).

${ }^{99}$ At the direction of the U.S. Congress, the President undertook negotiations in 1988 to amend the GATT in this way, but the negotiations proved unsuccessful. See 19 USCS $§ 2397$ note. 


\section{Worker Migration}

Commitments in trade agreements regarding the movement of people began as early as the year 1217, and have often been included in modern treaties on friendship, commerce, and navigation. ${ }^{101}$ At the U.N. Conference on Trade and Employment in 1948, the governments approved a Resolution suggesting that the U.N. Economic and Social Council, in conjunction with the ILO, consider the problems of temporary or seasonal migration of workers for the purpose of formulating conventions and model bilateral agreements so that governments may coordinate their actions to ensure mutually advantageous arrangements and fair conditions for the workers concerned. ${ }^{102}$ After 1948 , the issue of worker migration disappeared from the global trade agenda.

Attention to the temporary movement of workers is one of the most positive features of the GATS. So far, the commitments made by governments have been meager. ${ }^{103}$ Perhaps the ongoing

\footnotetext{
${ }^{100}$ To be sure, both issues relate to the trade and employment linkage. Nevertheless, I would exclude them for pragmatic reasons. The trade-related aspects of worker migration is a GATS issue and should be addressed by the WTO Council for Trade in Services or its subsidiary bodies. The issue of fair labor standards is very controversial in the WTO and any proposal to authorize a committee to consider it would doom that proposal to failure. The author is under no delusion as to the political likelihood that the WTO would actually set up a Committee on Trade and Employment. But I want the opponents to have to articulate why such a Committee is not appropriate for the WTO without having the easy retort that the WTO should not deal with fair labor standards.

${ }^{101}$ See Jean Baneth, Comment, in Anne O. Krueger (ed.), The WTO As An International Organization (Chicago, University of Chicago Press, 1998) at 271, 274 \& n. 1 (discussing the England-Norway commercial agreement of 1217); Herman Walker, Jr., Modern Treaties of Friendship, Commerce and Navigation, 42 Minnesota Law Review 805, 806 (1958).

${ }^{102}$ U.N. Conference on Trade and Employment, Resolution to the Economic and Social Council Relating to Employment, reprinted in Michael Hart (ed.), Also Present at the Creation (Ottawa, Centre for Trade Policy and Law, 1995) at 237-38.

${ }^{103}$ See Allison M. Young, What's Next for Labor Mobility Under GATS?, in Pierré Sauve \& Robert M. Stern (eds.), GATS 2000. New Directions in Services Trade Liberalization (Washington, Brookings, 2000) at 184, 187. Governments can negotiate commitments to liberalize entry opportunities for foreign persons through GATS Article XVIII (Additional Commitments), or instead through Articles XVI:2(a), XVI:2(d), and XVII:1.
} 
Doha Round will deepen those commitments. ${ }^{104}$ Allowing greater movement of persons delivering services can aid the economies of both sending and receiving countries, and can also help individual workers enhance their self-fulfillment. In the past few years, many analysts have taken note of the constructive potential of WTO negotiations on Mode $4 .{ }^{105}$ Freedom of movement for workers (and for students consuming educational services) should be a high priority, even in a time of heightened border insecurities.

In 2004, the World Commission on the Social Dimension of Globalization pointed out "the lack of a coherent framework for the cross-border movement of people." ${ }^{106}$ The Commission recommended the initiation of a preparatory process towards an institutional framework for the movement of people across national borders that would be similar to multilateral frameworks that already exist (or are under discussion) for goods, services, technology, investment, and information. ${ }^{107}$ In my view, a multilateral framework is truly needed and should involve better coordination between the WTO, the ILO, and the IOM. ${ }^{108}$

\section{Fair Labor Standards}

\footnotetext{
${ }^{104}$ See Gary G. Yerkey, U.S. Industry Sees Progress in Mode 4 As Key to Success in Overall WTO Trade Talks, BNA Daily Report for Executives, 4 February 2005, at A-19.

${ }^{105}$ For example, see Christine Breining-Kaufmann, Rajesh Chadha \& L. Alan Winters, The Temporary Movement of Workers - GATS Mode 4, in L. Alan Winters \& Pradeep S. Mehta (eds.), Bridging the Differences. Analyses of Five Issues of the WTO Agenda (Jaipur, CUTS, 2003) at 111; Steve Charnovitz (2003), Trade Law Norms on International Migration, in Migration and International Legal Norms, supra note 44, at 241; Sumanta Chaudhuri, Aaditya Mattoo \& Richard Self, Moving People to Deliver Services: How Can the WTO Help?, 38 Journal of World Trade 363 (2004); UN Millennium Project, Task Force on Trade, Trade for Development, § 4.4.1 (presenting several thoughtful proposals for Mode 4 negotiations), available at $<$ http://www.unmillenniumproject.org/reports/reports2.htm>.

${ }^{106}$ World Commission on the Social Dimension of Globalization, supra note 97, para. 416.

${ }^{107}$ Id. para. 444.
}

${ }^{108}$ See Steve Charnovitz, Assessing the ILO's Efforts to Develop Migration Law, 30 Legal Issues of Economic Integration 193 (2003). 
The third area of employment policy where the WTO could do more is labor standards. ${ }^{109}$ Back in 1948, a provision on "Fair Labour Standards" was included in the ITO Charter and intended to be part of the trading system. ${ }^{110}$ This is still a good idea, as there are many trade-related labor issues - such as the working conditions in export processing zones - that are not currently being dealt with by the WTO. ${ }^{111}$ In recent months, the U.S. government has brought up the issue of core labor standards during country reviews in the WTO Trade Policy Review Mechanism. ${ }^{112}$

In the ITO Charter of 1948, the governments evinced a recognition that "all countries have a common interest in the achievement and maintenance of fair labour standards related to productivity, and thus in the improvement of wages and working conditions as productivity may permit."113 That sentence contains several important thoughts: One is that improvements in productivity may enhance labor standards and wages. Another is that high labor standards not justified by productivity may not be beneficial. Another is that nations share a common interest in higher labor standards.

No intergovernmental declaration on labor standards emanated from the trading system after 1948 for almost 50 years. Then in 1996 the WTO trade ministers at Singapore declared: "We renew

\footnotetext{
${ }^{109}$ An excellent summary of the issue is: Trade-Labour Debate: The State of Affairs, CUTS Centre for International Trade, Economics \& Environment Research Report (Jaipur, CUTS, 2004). The Report opposes a WTO role in labor standards and states that the issue should be handled by the ILO. By contrast, other analysts support a WTO role. See, e.g., Robert Howse, The World Trade Organization and the Protection of Workers' Rights, 3 Journal of Small and Emerging Business Law 131 (1999); James Atleson, The Voyage of Neptune Jade: The Perils and Promises of Transnational Labor Solidarity, 52 Buffalo Law Review 85 (2004); Chantal Thomas, Should the World Trade Organization Incorporate Labor and Environmental Standards?, 61 Washington \& Lee Law Review 347 (2004).

${ }^{110}$ See ITO Charter, supra note 68 , art. 7.

${ }^{11}$ See Kimberly Ann Elliott \& Richard B. Freeman, Can Labor Standards Improve Under Globalization? (Washington, Institute for International Economics, 2003) at 134-35.

${ }^{112} 3 \mathrm{D}$, Practical Guide to the WTO for Human Rights Advocates (Geneva, 3D, 2004) at 30. The Trade Policy Review Mechanism is chartered in the WTO Agreement, Annex 3.

${ }^{113}$ ITO Charter, supra note 68 , art. 7.
} 
our commitment to the observance of internationally recognized core labour standards." ${ }^{114}$ The WTO Ministers at Singapore further stated that "The International Labour Organization (ILO) is the competent body to set and deal with these [core] standards, and we affirm our support for its work in promoting them." ${ }^{115}$ That the ILO is the competent body for labor standards is obvious, and no one has seriously argued that the WTO should poach on that turf. Although the statement by the Ministers is unobjectionable on its face, many analysts and stakeholders did object that the Ministers did not do anything tangible to support the ILO's work. ${ }^{116}$

Because the nations of the world have a common interest in improving labor standards, they also share an interest in assuring that the WTO and the ILO work cohesively. The linkages are numerous: Emancipating international trade will increase productivity which should tend to raise labor standards. Improving labor conditions in countries notorious for worker rights abuses will make it easier for those countries to export to consumers who care about the condition of the workers making the goods they buy. ${ }^{117}$ Raising worker productivity will expand output and enable countries to better compete in trade. These potential synergies need to be developed in a way that will allow the trade regime to help the labor regime.

${ }^{114}$ WTO Singapore Ministerial Declaration, supra note 77, para. 4.

${ }^{115} \mathrm{Id}$.

${ }^{116}$ See e.g., Brian Langille, Labor Rights, in P. J. Simmons \& Chantal de Jonge Oudraat (eds.), Managing Global Issues (Washington, Carnegie Endowment, 2001) at 469, 487 (stating that the Singapore Declaration rejected labor standards as a fit subject matter of WTO debate and dismissed the ILO as marginal to the efforts of the WTO).

${ }^{117}$ See Karen A. Tramontano, Stitching Up Global Labor Rights, Washington Post, 11 December 2004, at A23 (discussing the example of Cambodia). 
The relevance of labor policy to trade policy is actually just a subset of the broader relevance of labor policy to economic policy. ${ }^{118}$ Workers are the most valuable resource a country has for its development, and yet too often during the 1970s and 1980s, active labor market programs for workers were neglected by the World Bank. Several years ago, the World Bank recognized the gap in its own efforts, and began to devote attention and resources to social protection and labor markets. ${ }^{119}$

A holistic vision was put forward in 1981 in the encyclical Laborem Exercens. Pope John Paul II stated that "it is respect for the objective rights of the worker . . . that must constitute the adequate and fundamental criterion for shaping the whole economy, both on the level of the individual society and State and within the whole of the world economic policy and of the systems of international relationships that derive from it." ${ }^{120}$ The Pope referred to the ILO, and not the GATT, but surely the WTO today is one of the systems of international relationships that derive from the world economy.

Worker rights are now off the negotiating table at the WTO and likely to remain so for many years. Several reasons exist, but a major cause is surely Bill Clinton who as U.S. President confided to a reporter the coercive path he favored for worker rights at the WTO. Just before he arrived at the WTO Ministerial Conference in Seattle in late 1999, Clinton said that he favored a WTO working

\footnotetext{
${ }^{118}$ Friedl Weiss, Internationally Recognized Labour Standards and Trade, in Friedl Weiss, Erik Denters \& Paul de Waart (eds.), International Economic Law with a Human Face (The Hague, Kluwer Law International, 1998) at 79, 106.

${ }^{119}$ See World Development Report 2005, A Better Investment Climate for Everyone (New York, Oxford University Press, 2004) chap. 7 and the earlier pivotal World Development Report 1995, Workers in an Integrating World (New York, Oxford University Press, 1995).

${ }^{120}$ Laborem Exercens, 14 September 1981, para. 17, available at <http://www.vatican.va/holy_father/john_paul_ii/encyclicals/documents/hf_jpii_enc_14091981_laborem-exercens_en.html>.
} 
group to devise a set of core labor standards for trade agreements that would be enforced through trade sanctions. $^{121}$

The misplaced motivation of Clinton's remark touched off a firestorm of opposition within the WTO and was a factor in the failure of the Seattle Conference. By December 1999, it had become apparent that the issue of labor standards in the WTO was delicate, and no progress could be made in any proposal that endorsed trade sanctions as a way to enforce labor standards. Opinions differ on what Clinton's motivation was for making his incendiary remarks; perhaps he just misspoke. Whatever its rationale, Clinton's comment swept away the progress that had been made in the preceding years in explaining how the WTO could take up the issue of labor standards without committing to a sanction-based approach.

Several possibilities exist. For trade in goods, one can imagine a greater use of international product standards to guarantee that goods are produced under healthy working conditions. The WTO Agreement on Technical Barriers to Trade (TBT) calls on governments to use relevant international standards where they exist. ${ }^{122}$ Although the TBT Agreement appears to have been written carefully to preclude standards based on working conditions, ${ }^{123}$ the TBT definitions are written loosely enough for an expansive interpretation should governments want to do so. For trade in services, one can imagine stitching together several GATS provisions to promote specified labor standards in services sectors. ${ }^{124}$ Indeed, David Richardson, a well known trade economist, has suggests that the GATS

\footnotetext{
${ }^{121}$ See Michael Paulson, Clinton Says He Will Support Trade Sanctions for Worker Abuse, Seattle Post-Intelligencer, 1 December 1999, at A1.

${ }^{122}$ Agreement on Technical Barriers to Trade (TBT Agreement), art. 2.4.

${ }^{123}$ See TBT Agreement, Annex 1, paras. $1 \& 2$ (referring to "related" processes and production methods).

${ }^{124}$ For example, GATS arts. V bis, VII:5, XIX:2 (attaching conditions), XVIII (additional commitments).
} 
could be expanded to cover market-supportive regulation regarding labor policies. ${ }^{125}$ His proposal suggests a WTO Agreement on Trade-Related Worker Agency Services to cover freedom of association and the right to collective bargaining.

If labor standards do not come into the WTO as a discrete trade issue, they may come in instead as a "human rights" issue. Because the United States has never pressed for its inclusion into the WTO, human rights does not carry the same baggage that labor rights carries. To be sure, the WTO member governments that have been so defensive about worker rights, such as India, might be similarly antagonistic to human rights as a trade goal. But given the commitment within the United Nations and in many countries to the primacy of human rights, one cannot easily predict the outcome of a concerted effort to add a human rights dimension to the WTO. In recent years, many analysts have written about human rights as a WTO issue in a favorable light. ${ }^{126}$ Others decry the idea of taking human rights into account at the WTO preferring to limit the arenas in which human rights can be pursued. How this tension plays out will be interesting to watch. It may be that when the issue of

\footnotetext{
${ }^{125}$ J. David Richardson, The WTO and Market-Supportive Regulation: A Way Forward on New Competition, Technological and Labor Issues, The Federal Reserve Bank of St. Louis Review, July/August 2000, at 115, 116, 121-23.
}

\footnotetext{
${ }^{126}$ For example, see Sarah H. Cleveland, Human Rights Sanctions and International Trade: A Theory of Compatibility," 5 Journal of International Economic Law 133 (2002); Thomas Cottier, Trade and Human Rights: A Relationship to Discover, 5 Journal of International Economic Law 111 (2002); Lianne M. Jarvis, Women's Rights and the Public Morals Exception of GATT Article 20, 22 Michigan Journal of International Law 219 (2000); Ernst-Ulrich Petersmann, Time for a United Nations "Global Compact" for Integrating Human Rights into the Law of Worldwide Organizations: Lessons from European Integration, 13 EJIL 621 (2002); Ernst-Ulrich Petersmann, The "Human Rights Approach" Advocated by the UN High Commissioner for Human Rights by the International Labour Organization: Is It Relevant for WTO Law and Policy?, 7 Journal of International Economic Law 605 (2004); Stephen J. Powell, The Place of Human Rights in World Trade Organization Rules, 16 Florida Journal of International Law 219 (2004); Federico Lenzerini, International Trade and Child Labour Standards, in Francesco Francioni (ed.), Environment, Human Rights and Trade (Oxford: Oxford University Press, 2001) at 287. For a skeptical view, see Philip Alston, Resisting the Merger and Acquisition of Human Rights by Trade Law: A Reply to Petersmann, 13 EJIL 845 (2002).
} 
core labor standards eventually enters the WTO, it does so under the banner of human rights, rather than as a distinct objective. ${ }^{127}$

\section{Conclusion}

The purpose of this article is to suggest that the WTO adopt a durable employment dimension and to propose key elements for it. The Preamble of the WTO makes a bow to "ensuring full employment," but none of the actual rules drafted during the Uruguay Round do anything concrete to achieve this goal. Expanding the level of international trade may increase worker remuneration and purchasing power, but trade is a blunt instrument for governments to use to combat structural unemployment and chronic poverty.

Instead, governments need to use appropriate employment policy. The difficulty, however, is that because of perceived international competition, governments may not implement the employment and labor policies that would be optimal for them. Similarly, dysfunctions in employment policy can hinder trade negotiations. Because of perceived unfairness in trade due to horrible labor conditions in some countries, governments may resist the acceptance of goods produced under such conditions. Because of labor market failures that prevent redundant workers from getting reemployed, governments may drag their feet in implementing trade liberalization. ${ }^{128}$ Furthermore, WTO rules on subsidies may encroach on the policy space needed by governments.

The existence of these international interactions between trade and labor provide the justification for a comprehensive international policy to manage the trade-labor connection. One element is to prevent WTO rules from interfering with legitimate labor policy at the national level. Another is maintain a proper balance between economic and social factors of development. Another is to promote the employment and social preconditions for trade liberalization. Not all aspects of such

\footnotetext{
${ }^{127}$ See Philip Alston (ed.), Labour Rights as Human Rights (Oxford: Oxford University Press, 2005).

${ }^{128}$ For example, in the early 2000s, the Bush Administration imposed heavy tariffs on steel and endorsed new subsidies for U.S. farmers.
} 
policies need to be addressed within the WTO, but even the ones outside the WTO's competence might benefit from some WTO involvement.

Twenty years ago, I observed that jobs were replacing gold as the modern measure of a favorable balance of trade. ${ }^{129}$ What I meant was that poor outcomes in the labor market would become more of a constraint on the ability of governments to liberalize. ${ }^{130}$ I was not suggesting that only exports create jobs, or that imports always destroy jobs. If such effects actually occurred, that would turn the trade equation into a zero-sum employment game. Surely that view of trade ignores both theory and reality.

Looking back, my observation was a tad too pessimistic. In the intervening years, many governments have liberalized trade, often in the face of high unemployment. Nevertheless, a great deal more liberalization remains to be accomplished in the years ahead.

Poor domestic and international policies on employment creation will continue to be a drag on the ability of governments and societies to embrace the benefits of trade liberalization. To remedy this situation, the WTO should admit that the aspirations about employment in the Preamble to the WTO Agreement cannot be satisfactorily achieved without the use of social policy instruments at both the domestic and the international levels. As a first step, the WTO's shadowy employment dimension should be better developed so that the WTO works with other international agencies to help countries recover from globalization-induced unemployment.

Just as international trade policy is too important to be left to the WTO, international employment policy is too important to be left to the ILO (or to meetings of the G-8 Labor and Employment Ministers). In my view, the WTO itself has a complementary role to play. Furthermore,

\footnotetext{
${ }^{129}$ See Charnovitz, supra note 87, at 170.

${ }^{130}$ This is especially true in the United States where President Bush (according to one of his aides) "strongly opposes any treaty or policy that would cause the loss of a single American job." See Putin Signs Kyoto Protocol-What's Next?, 15 Business and the Environment (1 December 2004) at 4.
} 
governments need to enhance the coordination of multilateral organizations so that interconnected economic and social goals can be integrated and promoted more successfully. The world community took up this task 60 years ago in the establishment of the U.N. Economic and Social Council (at the suggestion of the Bruce Committee). Sadly, the integration of social and economic objectives remains in its infancy. Going forward, such integration will also need to take account of environmental objectives.

In discerning the right path forward, governments and stakeholders can benefit by learning from history. A key development was the U.N. Conference on Trade and Employment of 1946-48 and the creation of the GATT. These multilateral efforts to construct economic and social governance had roots in an earlier era of institution-building when the ILO and League of Nations were created. The unique mission of the ILO called for a new building for which the foundation stone was installed with great ceremony in 1923 . That impressive structure, named for the internationalist William Rappard, now houses the WTO. When the foundation stone was laid down, ILO Director Albert Thomas placed a piece of parchment under the stone on which a motto for the ILO had been inscribed. The motto is: "Si vis pacem, cole justitiam." If you wish for peace, cultivate justice. ${ }^{131}$ That's a good motto for the ILO and would be a good motto for the WTO. ${ }^{132}$ In the 21 st century, let us renew global efforts to achieve those timeless aspirations.

\footnotetext{
${ }^{131}$ Thomas, supra note 57 , at 12 .

${ }^{132}$ To my knowledge, the WTO does not have an organizational motto.
} 